\title{
Learning History by using E-Learning Module Based on Sofware Flipbook Maker
}

\author{
L.R. Retno Susanti \\ \{retno_susanti@fkip.unsri.ac.id\} \\ History of Education, Sriwijaya University, Indonesia
}

\begin{abstract}
This scientific work is titled Learning History Using the E-module Sofwarebased FlipBook Maker. As for the purpose of writing this scientific work to know the learning of history by using a Sofware based E-module FlipBook Maker. This scientific work uses the library study method of several research results that have been done by researchers with a fairly satisfactory success rate. Historical learning is a very complex process because it is abstraction. Therefore, it is necessary to use the system of information technology to make it easier for learners to understand the material history, then in the learning of history need to use a Sofware based E-module FlipBook Maker. Learning with a Sofware-based E-module FlipBook Maker gives learners the possibility to learn according to their abilities at the pace of their learning. As for implementation in the learning process with the use of this Sofware FlipBook Maker E-module, educators act as teachers who facilitate the learning process. So that students in the study room can play an active role by studying the materials and performing the tasks or exercises that have been designed in the module to facilitate students ' understanding of the learning materials so that they can Improve learning outcomes.
\end{abstract}

Keywords: Learning History, Elearning Module, Sofware-based FlipBook Maker.

\section{Introduction}

The rapid development of information technology today, needs to be addressed by the education world. Technological advances must be brought into the classroom for better learning. Current students are also very familiar with the technology so that lecturers should also follow the developments. Various software produced by computer technology can be utilized in the educational world, especially in learning. Some research that has been conducted by researchers by utilizing computer technology has positive impact both on interest, motivation, thinking skills and learning outcomes [1].

Significant results from some of the above studies occur because learning by utilizing technology is more interesting, requires creativity and up-to-date or in accordance with the development of current student environment.Therefore, it needs more innovation to create learning that is more interesting and interested by students.

In South Sumatra, there are many historical relics that have not been used as learning resources. Especially the prehistoric relics scattered in the highlands of South Sumatra are often referred to by Pasemah megalithic cultural archaeologists. The discoveries of prehistoric times include megalithic sites, even recognized as the most comprehensive megalithic site of prehistoric times in Indonesia even around the world. Seeing the historical relics is a pity that has not been packaged or utilized optimally as a source of learning in the learning of history especially local history learning. Thus on the other hand is actually a lot of resources learning 
around the life of learners that can be utilized for learning. This phrase is reinforced by Parceval and Ellington, that from a wide number of sources learn only textbooks are widely utilized. This condition is compounded by the use of the book as a learning resource also still depends on the teacher's presence, if the teacher is not present then other learning resources including the evidence can not be utilized by learners. Therefore the presence of the teacher is absolutely necessary [2].

The courses of ancient Indonesian history are compulsory courses that must be attended by students of the history Education program. In the course of ancient Indonesian history, students learn everything about ancient humans, cultures, megalithic buildings and civilization by involving skills and reasoning. Historical learning is developed based on experiments (inductive) or based on theory (deductive) so that students are trained to think scientifically.Learning history is a very complex process. Lecturers should be able to explain the abstract history material into real so that students understand the historical material easily [3].

In studying history, certain specific learning techniques are indispensable with regard to the characteristics of the history as procedures and processes. Some of the specific characteristics of historical sciences are among others: a) The history of more abstract, B) Learn the simplification of the actual historical sciences, c) The study material history starts from the easy to the difficult, and D) lesson materials History not only solves the problems. The historical learning techniques that are suitable for such abstract things are by imagining or creating depictions of the matter in real or imitation/modeling. The imagery can help students to remember the material discussed in the study of history, especially of the pre-existing or historical material [4].

Based on preliminary study to the historical education students of the Education Department of IPS FKIP Unsri, the utilization of information technology today is often used by students. They are more pleased and often use electronic appliances such as computers, laptops, mobile phones, and others in everyday life.Therefore, the habits and hobbies of such students need to be utilized in the learning history process. Therefore the presence of Internet in education is already a necessity to develop a more conducive and interactive teaching learning situation in historical learning [5],[6].

Therefore, the development and use of E-module software-based FlipBook maker is very necessary to be implemented for the study of history in the history education Program in order to increase motivation, interest, activation, and independence of students To learn that they have a satisfactory learning outcome. The E-module software-based FlipBook maker displays text, images, animations, and videos through a computer's electronic device.Interactive electronic teaching materials can reduce the use of paper in the process of learning.In addition, the E-module software-based FlipBook maker is expected to be used as an efficient and effective alternative learning resource.

Based on the explanation above, the problem can be formulated as follows.How is the development of E-module software-based FlipBook maker for learning history with megalithic relics in Pasemah on the subject of ancient Indonesian history? 


\section{Review of Library}

\subsection{Learning History}

The history derives from the word syajaratun meaning tree. History according to the Great Dictionary of Bahasa Indonesia is: 1) the Origins of genealogy; 2) events and events that really happened in the past.Historical learning requires a learning resource to increase students ' interest in learning history.Therefore, teachers must seek effective teaching materials that are intended for students because students are active in studying science.In addition, learning is a mental/psychic change that takes place with full awareness in learners through positive active interactions with the environment and that results in a change in understanding, skill, and attitude.The change could be a new outcome or refinement to the results previously obtained and relatively constant or consequential [7].

To gain the ability of knowledge of the historical, the purpose of the learning of its own history in order to realize the figure of individuals who have a sense of love towards the homeland, so that with such a sense of love can be expected to bring This homeland is in the better direction.Historical learning can help learners to understand the behavior of people in the past, present, and future.It is clear that historical lessons become a vehicle for learners to learn about the process of change and development of the community and to embed knowledge and good values in learners [3].

With the reason it is expected by the existence of teaching materials in the form of Emodule software-based FlipBook maker of learning that specifically discusses the material local history of the Megalithic Pasemah website, especially on the site of Tegurwangi and surrounding areas, can Add reference to the learning of ancient Indonesian history.

\subsection{Module characteristics}

The Bahasa Indonesia dictionary states that modules are a learning activity that allows learners to learn with the help of a minimum of educators, which includes planning and objectives to be achieved. Clearly, providing learning materials, tools needed in learning, tools for assessing and measuring learners ' success in completing learning.In line with that, Prastowo argues that a module is a structured teaching material that uses easy-to-understand language according to the characteristics of learners, prepared to make students study independently With minimal guidance from educators [8].

Generally each type of teaching material has its own characteristics. The module as a teaching material also has a characterisk that distinguishes it from other teaching materials.First, the design of modules is aimed at self-learning systems. Secondly, the module is structured as a thorough and organized learning program.Third, in a module there is a load of purpose, content or activity, and an assessment or evaluation tool.Fourth, the presentation of the module teaching materials is communicative or in two directions.Fifth, the existence of modules designed can enable reducing the role of educators in delivering material.Sixth, the discussion in the module is arranged in a focused and measurable order.Seventh, the module is designed to increase the learning activity of the learner [8].

According to the Ministry of National Education that the characteristics of a module such as self intructional, self contained, stand alone, adaptive, and user friendly [9].

a. Self intructional, in this case the module is designed to provide allows for the learning to teach itself without depending on the other party, therefore there are some things to be considered in writing a module, Include: a. Facilitate learning to learn completely through the preparation of specific materials or packaged in small units. $b$. 
Support Participant's understanding through the clarity of the material displayed by providing examples and illustrations. c. Provide possibilities for the learnings to respond and measure the level of mastery on learning materials by providing training, duties and the like. d. The learning materials presented are tailored to the context of the task and the learning environment. e. Communicative language and simple. f.Contains a summary of the learning materials. g. Contains assessment instruments that enable participants to measure their own success in learning. h. Provide the possibility for the adherence to know the level of his or her content in the material through the provision of feedback. i. Available information on referrals that support learning materials in the module.

b. Self contained, this means that a module must contain the scope of the whole material needed in the learning according to the competencies that want to be achieved in the learning so as to enable the learning to learn the modules The whole.Distribution of material from one competency unit can be done if it is needed by observing the principles of prudence and competence.

c. Stand Alone means that the use of modules can be done without depending on the existence of other learning media, including in the study of materials and work on the tasks contained in the module

d. Adaptive; Modules must be able to adapt to the development of science and technology, including in terms of use should be flexible including can be used on various types of hardware

e. User Friendly; The exixtence of the instructions in the module should be designed to facilitate the learning of access and response to the needs of the learning, in addition, the information presented in the module should also use language and terms that are easy to understand by the adherent so that it can be said to be friendly with the user.

Based on the above opinion, it s understandable that the characteristics of a module, among others, can be used for self-learning, containing all the full and complete learning components including evaluation and feedback, so that it is possible that learning is complete by learners, its use is not dependent on other media, can adapt to development of science and technology and provide convenience for its users both in Understand the contents of the module itself.

\subsection{Module Components}

Broadly speaking modules have components like teaching materials in general. Sungkono argues that a module has several components, such as the review of subjects, introduction, learning activities, exercises and grids answer, summary, formative test and the answer key [10].

Depdiknas explains that a module must contain important components consisting of the opening part, the core part and the final part. The opening section includes the title, Table of contents, information map, List of competency objectives, preliminary tests. The core section includes material review, relationships with other materials, material descriptions, assignment, summaries. The final section includes the glossary, final tests and indexes [11].

Based on some of the above opinion it can be understood that a module consists of several components is the beginning or the introduction, the core part or the learning activity and the end or the cover. 


\subsection{Learning by Module}

The module is a complete and structured teaching material that refers to the curriculum, using language that is easy to understand, in accordance with the characteristics of the students.According to the Prawiradilaga module is a dynamic teaching material because it can be used in both self-learning and learning in classrooms that involve the role of educators.Learning by module is a learning that gives learners the possibility to learn according to their own pace and learning ability.So it can be said that the learning by using a module in principle aims to increase the effectiveness and efficiency of learning in terms of use of time, funds, facilities, and energy precisely [12].

In the learning process, it can be said that modules are teaching materials used and utilized as learning aids to help learners master the learning materials in accordance with the established indicators.In this case, the existence of the module is utilized as a facility that can be used by learners to learn the material independently according to the capabilities and speed of its own learning, while educators who act as facilitators can provide an overview of the material to be learned to the learners [13].

The use of modules in learning independently or individually is very possible because as a module teaching material contains objectives, instruction sheets, reading materials, answer keys, and evaluation tools. Whereas in the conventional learning process module can be used as an alternative form of presentation of material in learning [14].

Based on the above opinion it is understandable that modules are teaching materials that can be used in conventional learners that involve the role of educators as both teachers and learning independently to help overcome time constraints Learning opportunities in the lecture room.Learning with modules gives students the possibility to learn according to their learning abilities and pace.The implementation of learning with modules in this research is the use of digital modules in the learning process where educators act as teachers who facilitate the learning process so that students in the lecture room can Play an active role by studying the materials and performing assignments or exercises that have been designed in the module to facilitate participants ' understanding of the learning materials so as to improve learners ' learning outcomes.

\subsection{Digital Module (E-Module)}

The development of information media today began to experience the transition from print media to digital media. This has an impact on the educational world, especially in term of the presentation of teaching materials. The presentation of teaching materials including modules is not only limited to print media limit, but already utilize electronic media or digital media. The digital module is a form of presentation in the electronic format of the material that is composed in whole and structured into the smallest learning unit to achieve specific learning objectives accompanied by a navigation link that can be Create student interactivity on the program and can be equipped with audio, image, video, and animation content to enrich learning experience [15].

In line with the above opinion, digital modules can be interpreted as teaching material that are systematically designed based on a specific curriculum and packaged in specitif time units dispayed using electronic devices such as computers or Android [16]. Digital modules also have interactive properties due to easy navigation, image display, audio, video, and animation that provide variety, as well as feedback through specific formative tests or quizzes [17]. 
A digital module is a learning tool designed to achieve certain competencies in which it contains material, methods, restrictions and how to conduct the process of conducting the learning outcomes structured and presented with Utilizing communication technology and information in the form of interned and electronic devices [18]. In addition, digital modules are teaching material based on information communication technology that has various advantages, among others; Operation of the generated modules can be done easily by the user, modules can be equipped with background music, video, slide show, can be learned online and offline, learning evaluation can be made using the application quiz qreator, can be opened via a computer or a smarphone, this module can be used as a learning resource for students who want to learn without time limitation [19].

Based on the above opinion can be concluded that the digital module is a form of presentation of a material module in electronic format, in which there is a navigation link that can facilitate interactivity between participants students with the program and can be equipped with audio, image, video and animation content, can be learned online or offline so that it can enrich the learning experience.

\subsection{Flipbook}

Flipbook is one kind of animated book display in electronic or digital format back page. The use of this Flipbook-shaped digital book can make users feel like they're opening a book physically. Moving between pages can be done by touching and unfolding a page as our finger flips a page of the book, and the page will be folded as the paper is being bent. In addition to the way dragging, page transfer can also be done by utilizing the navigation buttons available [20].

E-module in the form of Flipbook maker developed in this study using the software Flipbook maker.FlipBook Maker is one of the software that can change the look of books or other teaching materials into a digital book behind the form of a page (Flipbook) [21].This software is a powerful software designed to convert packaging files from PDF, PowerPoint, Word, and Excel formats into a book, magazine or catalogue, etc. resulting in a more attractive look and be published digitally.Various features such as zooming to zoom, word search, bookmarks, and thumbnails are available in this app [22].

This software is chosen because it has several advantages, among others, capable of inserting various media in a book or module that will be developed in a more varied media display, not only text, but also images, video, and audio so that the process Learning will be more interesting. The device also has designs and features such as background, control buttons, navigation bar sound. The animation effect at the time of page switching will make users feel like they're physically opening the book. The Output or the end result of this software can be saved to the format of HTML, EXE, ZIP, Screen saver and app. The HTML format allows uploading to the website online. EXE format for CD delivery, ZIP format for fast email and APP format for Smartphone use [20].

\section{Research Methods}

This type of research is developmet research using Alessi and Trollip development model consisting of 3 (three) stages namely planning stage, design stage, and development stage. This model was chosen because it focused on the development of non-printing product, has a simple and complete working way so that it is easy to follow and has a development 
model is also there is a formative evaluation and summative evaluation at the its development, which is Alpha test and Beta test [23].

This study was conducted on student of History Education study Program of FKIP Unsri. At the planning stage the researcher defines the scope of constraints based on need analysis, curriculum analysis, and sarana-prasarana analysis. Analysis of needs as a first step in developing E-modules for students is conducted through preliminary study to find out the obstacles faced in training learning and to know the needa of training participants in the process learning. Curriculum analysis conducted by researchers related to the scope of material that will be developed in the form of module teaching materials, and analysis of sarana-prasarana conducted related facilities and infrastructure available and can support the development of modules that researchers will do.

The next step of the researcher at the planning stage is to identify the student characteristics through documentation studies. The next step researchers are setting up constraints and obstacles in the development of the Flippbook-shaped digital module. The next step of the researcher is to discuss the initial idea, this needs to be done in determining the initial concept of the developmet of digital modules

At the design stage of the researcher develops ideas related to the concept of learning and material, followed by determining the software to be used, preparing the initial prototype ini the form of a draft module and creating a product design in the form of flowcharts and storyboard.

At the stage of the development of researchers prepare the text of megalithic relics in Pasemah, preparing images, audio, and video, preparing supporting materials, producing prototypes, conducting Alpha test (expert validation) to know the opinions and Input from the experts on the developed media.At this stage, researchers validate the product to some experts, i.e. material/language experts, design experts, and media experts to conduct assessment of the material/language aspects, design aspects and media aspects of the digital module developed later By conducting product revisions.

The researcher subsequently conducted a beta test to find the practically of the product, and perform the necessary revisions to obtain the finl prototype. At the final stage, researchers conduct field tests to determine the effectiveness of the digital modules developed. At this stage the revised product based on the beta test results tested in the lecture room. This trial is done by providing pretests and posttest. Furthermore, the data collection techniques in this research include interview techniques, poll, observation and studi results tests. Data analysis in this study uses qualitative and quantitative descriptive data analysis techniques.

\section{Results and Discussion}

\subsection{Results}

At the planning phase of the researcher has determined the scope of boundaries in this research, namely the development of E-modules in the form of FlipBook maker of megalithic relics in Pasemah.The scope of this limitation is determined by researchers based on the results of analysis of needs, curriculum and supporting Sarana-prasarana.Researchers have also identified student characteristics, particularly those of research subjects.Based on the results of identification known that students who are the subject of research in the category require the development of competence, understand enough internet, have a smartphone 
facility and able to operate it well, but not yet is optimally utilized in ancient Indonesian history learning.

At the design stage researchers have developed good ideas related to material content, appearance, images, video, audio, exercises and evaluation.Development of ideas conducted by researchers at this stage is based on the outline of the contents of the module.Next the researcher determines the software that will be used in the development of digital modules in the form of FlipBook maker, the main software used by researchers is flipbuilder, and supporting software in the form of Adobe Photoshop, Adobe priemere Pro CS 6, Videoscribe, and application iSpring Suite 8. Further researchers mumcreate product designs in the form of flowcharts and storyboards.

At the stage of development researchers prepare text, images, audio and video related to material and supporting material that will be loaded in the digital module followed by producing a Prototype E-module form Flipbook maker. After going through the planning phase, design, until the prototype oe E-module in the form of Flipbookmaker on megalithic relics in Pasemah, further alpha test, beta test, dan field test.

Alpha test is done to obtain the validation from experts in flipbookmaker form of Emodule that is developed by researchers both from material aspect, design and media aspect.At this stage researchers ask for advice, feedback, and commentary on experts consisting of material experts, learning design experts, media experts against E-modules in the form of flipbookmaker developed.Comments and suggestions are further made as material improvements to revise E-modules in the form of FlipBook maker until stated to be valid or eligible for testing.

Referring to Alessi and Trollip's development research model to know the practicality of the E-module in the form of Flipbook maker that researchers do is beta test. The beta test is done to 3 (three) student from high, moderate and low ability categories according to the opinions of Alessi and Trollip. In the early stages, researchers explain to students the purpose and objectives and procedures to be implemented in beta test activities.Furthermore, researchers observe the use of digital modules by students, based on observations conducted by researchers, students are known to be fluent enough in using E-modules developed, the constraints experienced by students occur at the time Perform the installation process of Emodule because at the time of beta test application E-module downloaded through Google Drive and require some action on the settings of the smartphone that the student used so that the installation process takes time A bit longer.

Beta test results are comments and suggestions and assessment related to the use of digital modules. Comments given by students on the average beta test say that E-Module form Flipbook maker that researchers developed already from the clarity of material. Images, video or sound, examples of problems, exercises and evaluation, easy to understand, can used repeatedly and practically because it is easy to use anytime and anywhere so that it can attract and motivate participants in learning the Megalithic relics in Pasemah. The advice obtained at the time of beta testing is the need for improvement to make the E-module easy to download, it has been followed by the researchers through revision by providing E-modules on the service Paly store applications so that the download and R-module installation becomes easier.

Practicality assessment results conducted by researchers through poll in beta test activity in student A showed a yield with a percentage of $89.09 \%$, student B obtained the result with a percentage of $96,09 \%$, and student $\mathrm{C}$ obtained percentage value of $94,55 \%$. In accordance with the practicallyof Riduwan modification (2010) that the percentage value of 81-100 is in a very practical category then based on the acquisition of poll results from respondents in 
practicality test of E-modules that researchers developed including in a very practical category [24].

The field trials of this study were conducted by giving a written test of pretest-postes. The implementation of test products begins with pretests to students.From pretests results obtained an average value of 42.67 with a category very less. The postest implementation was done at the end of the learning process to see the student learning results after using the E-module in the form of FlipBook maker developed by researchers.From the postest results obtained an average value of 85.83 with a good category.Based on the acquisition of Pretests and Postest values indicates the increase in the value (gain) of 43.17 and $\mathrm{N}$-gain value of 0.76 which belongs to the high category.This corresponds to the $\mathrm{N}$-gain value classification table according to Hake (1998) that the value obtained is 0.76 including the high category [25].

\subsection{Discussion}

This research has successfully developed E-module in the form of Flipbook maker on megalithic relics in Pasemah in the course of ancient Indonesian history. Based on the results of validation conducted on Alpha test with experts in terms of material, design and media, it can be concluded that E-module form Flipbook maker on megalithic relic material in Pasemah by researchers are valid and worthy in the next phase of research.

Beta test results against E-modules in the form of FlipBook maker that researchers developed showed that the E-modules that researchers developed are included in a very practical category so that it can be concluded that the E-modules are developed easy to use by Students in learning. This is in accordance with the opinions of Akker et al. practicality means the resulting product is easy to use by users in this case it is a student and educator [26].

Based on the results of the field trials conducted by researchers, where the average results of pre-test 42,67 and post-test 85.83 with average increase in the value (Gain) 0f 43.17 and the average $\mathrm{N}$-Gain value of 0.76 which belongs to the high category as well as the tes results of the deed with an average value of 90.22 that belongs to the high category is very good, it shows that E-module form Flipbook maker on megalithic relics in Pasemah developed researchers have an effectiveness to student learning outcomes [25]. This is in line with the previous research conducted by Mulyaningsih \& Saraswati (2017) under the title of implementing digital Learning Media book with FlipBook maker utilizing the SPSS 16 program shows that there is a digital use influence Book on the understanding of the concept and student learning outcomes from an average of 70 for the control class (normalized Gain 0.4 ) to 84 for the experimental class (normalized Gain 0.7 ), so that it can be concluded that the use of digital media book with FlipBook Maker is effectively used in learning [22]. Research conducted by Sugianto et al under the title "Virtual module: Multimediaflipbook basic Digital Engineering" also found that digital modules berbentukflipbookefeective used in learning, can increase motivation, interest and liveliness Learning and can help make it easier for learners to understand learning materials [27].

\section{Conclusion and Advice}

\subsection{Conclusion}

Based on the results that have been done about the development of E-modules in the form of Flipbook maker on megalithic relics in Pasemah, it can be concluded as follows: 
1. E-module form Flipbook maker on megalithic relics in Pasemah developed researchers have proven validity after the alpha test. This E-module has been tested through alpha testing with material experts, learning design experts, and media expert and is declared worthy or valid to be tested.

2. E-Module form FlipBook maker on megalithic relics in Pasemah has been tested for practicality after beta test, tested through 3 (three) low, moderate and high-skilled students with a percentage of $89.0,96.0$, and 94.55 or are in a very practical category;

3. E-module form Flipbook maker on megalithic relics in Pasemah has the effectiveness of learning outcomes of training participants. It can be seen from the results of pretests and posttest at the field test. The average result of the acquisition of Prestests value is 42.67 with a very less category and the average posttest is 85.83 with a good category, the average increase in the gain value of 43.17 and the $\mathrm{N}$-gain value of 0.76 with high category.

\subsection{Advice}

Based on the results of research that has been done about the development of E-modules in the form of Flipbook maker on megalithics relics in Pasemah, researchers can advise the following:

1. For students are expected to utilize the E-module L developed as a teaching material in the study of megalithic relics in Pasemah to improve competence and improve the independence of learning

2. For teachers are advised to use this developed E-module as a reference in developing teaching materials that will be used in learning activities in higher education.

3. For other researchers, it is expected that it can be used as a reference in relevant research or can improve the teaching materials that have been developed by making all materialof ancient Indonesian history

\section{References}

[1] Asyhar, Rayandra. Kreatif Mengembangkan Media Pembelajaran. Jakarta: Gaung Persada Press. 2011.

[2] Soejono, R. P. Jaman Prasejarah. Sejarah Nasional Indonesia I edisi ke-4 Departeman Pendidikan dan Kebudayaan. Balai Pustaka: Jakarta. 1984.

[3] Sadono, Mursetyadi Yuli dan Mhusinatun Siasah Masruri. Keefektifan VCT dalam Pembelajaran Sejarah Untuk Meningkatkan Nilai Nasionalisme, Demokrasi, dan Multikultural. Jurnal Harmoni Sosial. 2014. Volume 2 No.1: 73.

[4] Maswardi. Internet Sebagai Sumber Belajar dan Media Pendidikan. 2012. Retrieved February 10, 2013, from http://disdik-agam.org

[5] Rachman, F. A., Hartono, \& Gulo, F. Pengembangan Bahan Ajar Berbasis Multimedia untuk Pembelajaran Sejarah di Prodi Pendidikan Sejarah. Palembang: Program Pascasarjana, Unsri. 2015.

[6] Uno, H. B., \& Lamatenggo, N. Teknologi Komunikasi \& Informasi Pembelajaran. Jakarta: Bumi Aksara. 2010

[7] Winkel, W. S. Psikologi Pengajaran. Jakarta: Raja Grafindo Persada. 2016.

[8] Prastowo, A. Panduan Kreatif Membuat Bahan Ajar Inovatif. Yogyakarta: Diva Press. 2012.

[9] Departemen Pendidikan Nasional. Penulisan Modul. Jakarta: Departemen Pendidikan Nasional. 2008. 
[10] Sungkono. Pengembangan dan Pemanfaatan Bahan Ajar Modul dalam Proses Pembelajaran. Jurnal Majalah Ilmiah Pembelajaran. 2009. Volume 5 N.

[11] Wicaksono, W., Sutrisno, S., \& Murtiono, E. S. Pengembangan Modul Pembelajaran Online Sebagai Media Pembelajaran Pada Mata Pelajaran Gambar Teknik Kelas X Teknik Gambar Bangunan Di SMK Negeri 2 Sukoharjo. Indonesian Journal Of Civil Engineering Education. 2015. Volume $2 \mathrm{~N}$.

[12] Prawiradilaga. Dewi. Prinsip Desain Pembelajaran. Jakarta: Prenada Media Group. 2008.

[13] Lestari, W. Pengembangan Modul Pembelajaran Bahasa Inggris Berbasis Andragogi pada Program Studi Pendidikan Biologi di Universitas Muhammadiyah Palembang. Tesis. Palembang: FKIP Unsri. 2015.

[14] Rufii, R. Developing Module on Constructivist Learning Strategies to Promote Students' Independence and Performance. International Journal of Education. 2015.

[15] Sefitri, R. S. Pengembangan E-Modul Ilmu Pengetahuan Sosial dengan Tema Globalisasi berbasis Problem Based Learning untuk Siswa Kelas VIII di Sekolah Menengah Pertama. Tesis. Palembang: FKIP Unsri. 2014.

[16] Jaenudin, A., Baedhowi, \& Murwaningsih, T. The Effectiveness of the E- Module of Economics Learning on Problem-Based Learning used to Improve Students' Learning Outcomes. Social Science, Education and Humanities Research (ASSEHR). 2017. Volume 158.

[17] Istuningsih, W., Baedhowi, B., \& Sangka, K. B. The Effectiveness of Scientific Approach Using E-Module Based on Learning Cycle 7E to Improve Students' Learning Outcome. International Journal of Educational Research Review. 2018. 3(3), 75-85.

[18] Winaya, I. K. A., Sindu, I. G. P., \& Darmawiguna, I. G. M. Pengembangan E- Modul Berbasis Project Based Learning Pada Mata Pelajaran Pemrograman Web Kelas X Di Smk Negeri 3 Singaraja. Jurnal Pendidikan Teknologi Dan Kejuruan. 2016. Vol.13, No, 198.

[19] Purwaningtyas, Wasis D. Dwiyogo, I. H. Pengembangan Modul Elektronik Mata Pelajaran Pendidikan Jasmani, Olahraga, Dan Kesehatan Kelas Xi Berbasis Online Dengan Program Edmodo. Jurnal Kesehatan Masyarakat Nasional. 2017. 5.

[20] Hidayatullah, M. S. Pengembangan Media Pembelajaran Berbasis Flip Book Maker Pada Mata Pelajaran Elektronika Dasar Di Smk Negeri 1 Sampang. Jurnal Pendidikan Teknik Elektro. 2016. 05, 83-88.

[21] Rasiman, \&Pramasdyahsari, A. S. Development of Mathematics Learning Media E- Comic Based on Flip Book Maker to Increase the Critical Thinking Skill and Character of Junior High School Students. International Journal of Education and Research. 2014.

[22] Mulyaningsih, N. N., \& Saraswati, D. L. Penerapan Media Pembelajaran Digital book DenganKvisoftflipbookMaker. Jurnal Pendidikan Fisika Universitas. 2017.

[23] Alessi, S. M., \& Trollip, S. R. Multimedia for Learning Methods and Development. Boston: Allyn and Bacon. 2001.

[24] Riduwan. Belajar mudah penelitian untuk guru, karyawan dan penelitipemula. Bandung: Alfabeta. 2010.

[25] Hake, R. Interactive-engagement versus traditional methods: A six-thousand-student survey of mechanics test. American Journal of Physics. 1998.

[26] Akker, J. van den, Bannan, B., Kelly, A., Nieveen, N., \&Plomp, T. An introductionto educational design research. Proceedings of the seminar conducted at the East China Normal University, Shanghai (PR China). 2010.

[27] Sugianto, D., Abdullah, A. G., Elvyanti, S., \& Muladi, Y. Modul virtual: Multimedia flipbook dasar teknik digital. Jurnal Invotec. 2013. IX(2), 101-116. 